\title{
Comparative and competitive advantage of soybean cultivation in Noakhali and Laxmipur District of Bangladesh
}

\author{
M. A. Salam* and M. Kamruzzaman \\ Department of Agricultural Economics, Bangabandhu Sheikh Mujibur Rahman Agricultural University (BSMRAU), \\ Gazipur, Bangladesh, *E-mail: salamecon@gmail.com
}

\begin{abstract}
The study highlighted different socio-economic aspects of soybean cultivation in Noakhali and Laxmipur district of Bangladesh. The issues were: cost and return of soybean and its competing crops cultivation, competitive and comparative advantage of soybean production, constraints to higher production, and farmers' attitudes towards soybean cultivation in Bangladesh. The average yield of soybean, groundnut, cowpea and grasspea were $1813 \mathrm{~kg} / \mathrm{ha}$, $1473 \mathrm{~kg} / \mathrm{ha}, 871 \mathrm{~kg} / \mathrm{ha}$ and $1076 \mathrm{~kg} / \mathrm{ha}$, respectively. The net return received from soybean, groundnut, cowpea and grasspea cultivation were estimated at Tk. 25599/ha, Tk. 17047/ha 11805 and Tk. 8825/ha, respectively. The average benefits cost ratios of soybean, groundnut, cowpea and grasspea production were 1.43, $1.26,1.28$ and 1.29 over full cost, respectively. The estimated DRC value for soybean production was found 0.55 which clearly indicate that the production of soybean in Bangladesh has comparative advantage rather than import. Functional analysis showed that TSP, MP, gypsum and pesticide use had positive significant impact on soybean cultivation. Although the cultivation of soybean was found to be profitable, many farmers showed negative attitudes toward its production. Scarcity of chemical fertilizers with its peak price, lack of HYV seed availability, lack of technical knowledge and natural calamities were found as the barriers of soybean crops expansion in Noakhali and Laxmipur district of Bangladesh.
\end{abstract}

Keywords: Soybean, Competitive and Comparative advantage, Profitability, Bangladesh

\section{Introduction}

Soybean is a high value and profitable crop. The economic viability of soybean production is determined by the commercial utilization of both its sub-products, meal and oil, which, account for about two thirds and one third of the crop's economic value, respectively. Soybean is the most important oil crops in Bangladesh. Out of the total cropped areas of 14.418 million ha, oil crops occupy about 0.366 million ha and the total production of the country stands at 0.786 million tones. Out of total oil copped area, Soybean occupies 0.041 million ha and production of soybean is 0.064 million tones (BBS, 2013). The supply of soybean is very lower than the demand. Considering the ever increasing demand of edible oil of our country, it is extremely needed to increase the total production of oil crops by fitting the existing cropping patterns by replacing the high yielding variety (HYV) with low yielding varieties through improving management practices as well as increasing the area of cultivation where ever possible. Different soya foods like soya milk, soya biscuits, soya chapatti can be prepared from soybean. These crops can fulfill a great part of oil gap in the country. It has also diabetic, medical, industrial and agricultural importance (Hossain et al., 1992).

We could access few studies about economics of soybean production such as, J. Mayta, (2014) analyze the profitability of small-seeded, large-seeded, and high-protein specialty soybeans using break-even (BE) analysis to establish guidelines for cultivar selection and adoption based on economic feasibility. Punit et. al. (2013) analyze that the average cost of cultivation was observed highest on medium farm as compared to large and small farmers. Average per hectare gross return from soybean for overall farmers was found to be Rs 43179.59. Cost of production per quintal of soybean was Rs. 1354.92 on overall farms. The benefit cost ratio was similar in case of medium and large farmers with 1.74 and slightly higher in case of small farmers 1.76. Jaiswal and Hugar (2011) shows that the net returns in soybean over jowar (868.72\%) was significantly higher than maize (121.67\%). Similarly, benefit cost ratio was higher in case of soybean (1.29) than that of maize (1.16) and jowar (1.05). The study also indicated that there have been incentives for farmers to grow soybean in kharif instead of its competing crops. Ogunsumi et al. (2007) shows that the internal rate of return (IRR) of 38 percent was estimated from the stream of netted real social gains at 1985 constant. The return to investment in soybean production technology is attractive and justifies the investments made on the technologies. Soybean provides a cheaper and high protein rich alternative substitute to animal protein. Olorunsanya et al. (2009) showed that $60 \%$ of the farmers had no former education with over $90 \%$ cultivating only a hectare of farm land to soybean. The costs and returns analysis revealed soybean production as a profitable enterprise with rate of return of $62 \%$ (Salam and Monayem, 2013). 
However, there is a dearth of this type of study. Therefore, the present study was undertaken to reflect the real situations of the existing production systems of soybean in Noakhli and Laxmipur district of Bangladesh. There are some studies on production and profitability of oilseed crops in Bangladesh. However, to the best of the researcher's knowledge, there is no specific study on comparative and competitive advantage of soybean cultivation. Therefore, the specific objectives of the study are: (i) to identify the socio-economic characteristics of soybean farmers; (ii) to analyze production and profitability of soybean farmers; (iii) to analyze the interrelationship between inputs and outputs of soybean production and (iv) to measure the comparative and competitive advantage of soybean farmer.

\section{Materials and Methods}

\section{Data and survey}

The required primary data was collected through a farm level survey. Multi-stage sampling technique was applied for this purpose. At the first stage, the country's two major soybean producing districts namely, Noakhali and Laxmipur of Bangladesh were purposively selected through consultation with the extension personnel and local scientists worked in the Oilseed Research Centre of Bangladesh Agricultural Research Institute. Then, from each district, the highest soybean producing upazila and from each upazila the top two soybean producing villages were purposively selected. Finally, 30 soybean growers, 15 cowpea growers, 20 groundnut growers and 15 grasspea growers were selected randomly from each village using the list of soybean, cowpea, groundnut and grasspea growers available with the local agricultural extension office. Primary data were collected from sample farmers with the help of a predesigned and pre-tested interview schedules during the period of January to June 2013. Thus, the survey interviewed 320 farmers belonging to four villages of Noakhali and Laxmipur district of Bangladesh.

\section{Analytical technique}

The analysis of data was based on tabular and descriptive techniques. In this research, tabular technique was applied for the analysis of data using simple statistical tools like averages and percentages. Higher production and profit are the two most important factors to motivate farmers towards any new technology. A detailed cost-benefit analysis was done for soybean farmers using tabular analyses techniques. The soybean production is likely to be influenced by different factors, such as, human labour, seed, and chemical fertilizer, etc. To determine the contribution of some important input on soybean production, the Cobb-Douglas multiple regression model was estimated because of the best fit of the sample data. The functional form of the Cobb-Douglas multiple regression equation was as follows:

$Y=A X_{1}^{b_{1}} X_{2}^{b_{2}}-------------------X_{n}^{b_{n}} e^{u_{i}}$

Where, the dependent variable $Y$ is the farm gross production and $X$ 's are farm specific those may influence farm output. The above function was converted to logarithmic form so that it could be solved by least square method i. e.,

$\log Y=\log a+b_{1} \log X_{1}+\ldots \ldots . .+b_{n} \log X_{n}+e^{u i}$

The empirical function was the following:

$\log Y=\log a+b_{1} \log X_{1}+b_{2} \log X_{2}+b_{3} \log X_{3}+b_{4} \log X_{4}+b_{5} \log X_{5}+b_{6} \log X_{6}+b_{7} \log X_{7}+U i$.

Where, $Y=$ Yield (Kg./ha);

$\mathrm{X}_{1}=$ Human Labour (man-day/ha);

$X_{2}=$ Seed $(\mathrm{kg} / \mathrm{ha})$;

$X_{3}=$ Urea $(\mathrm{kg} / \mathrm{ha})$;

$\mathrm{X}_{4}=\mathrm{TSP}(\mathrm{kg} / \mathrm{ha})$;

$\mathrm{X}_{5}=\mathrm{MP}(\mathrm{kg} / \mathrm{ha}) ;$

$X_{6}=\operatorname{Gypsum}(\mathrm{kg} / \mathrm{ha})$;

$\mathrm{X}_{7}=$ Cost of pesticide $(\mathrm{Tk} / \mathrm{ha})$;

$\mathrm{a}=$ constant value;

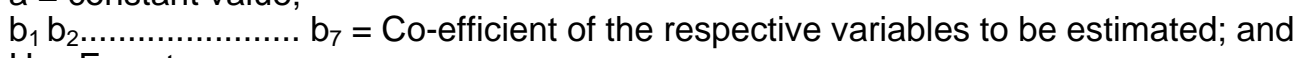

$\mathrm{U}_{\mathrm{i}}=$ Error term. 


\section{Estimation of domestic resource cost (DRC)}

Domestic Resource Cost (DRC) was estimated for evaluating the efficiency of production of soybean in relation to comparative advantage. It was calculated on import parity basis. It is the ratio of cost of domestic resources and non-traded inputs (valued at their shadow prices) of producing a commodity to the net foreign exchange earned or saved by producing the good domestically. In this study, value of tradable soybean was calculated on the basis of free on board (FOB) price of Chittagong port including ship freight charge and other associated costs. Domestic resources and non-traded inputs includes seed, human labour, land preparation cost, land rent, irrigation, manure and interest on operating capital and tradable inputs includes urea, TSP, MP and gypsum. Formally DRC is defined as:

$\mathrm{DRC}=\frac{\text { Cost of domestic resources and non }- \text { tradable inputs for producing soybean per metric ton }}{\text { Value of tradable soybean per metric ton }- \text { value of tradable inputs per metric ton }}$

Mathematically DRC is defined as:

$$
D R C=\frac{\sum D_{i j} V_{i}}{B_{i}-\sum T_{i k} V_{k}} \quad(j=1 \text {----------m; } k=1 \text {---------n) }
$$

Where,

$D_{i j}=$ Quantity of $j^{\text {th }}$ domestic resources and non-traded inputs used for producing soybean per metric ton

$V_{i}=$ Price of $j^{\text {th }}$ domestic resources and non-traded inputs $(\mathrm{Tk} / \mathrm{mt})$

$B_{i}=$ Border price of soybean $(\mathrm{Tk} / \mathrm{mt})$

$T_{i k}=$ Quantity of $k^{\text {th }}$ tradable inputs for producing soybean per metric ton

$V_{k}=$ Border price of tradable inputs $\mathrm{k}$ per metric ton.

If $D R C<1$, the economy saves foreign exchange by producing the soybean domestically either for export or for imports substitution. This is because the opportunity cost of domestic resources and non-traded inputs used in producing soybean is less than the foreign exchange earned or saved. In contrast, if DRC $>1$, domestic costs are in excess of foreign costs or savings indicating that the soybean should not be produced domestically and should be imported instead (Rashid, 2009).

\section{Results and Discussion}

\section{Socio-economic profile of the soybean farmers}

The adoption of new and improved technologies at farm level is mostly dependent on farmers' socioeconomic characteristics. Therefore, an attempt was made to identify different socio-economic characteristics that may influence farmers to adopt modern variety and their management technologies (Table 1). Age is an important factor that influences farmers' decision to adopt improved technologies. The average age of the soybean farmers was 47.18 years with minimum age of 18 years and the maximum of 80 years. Majority of the soybean farmers had primary and secondary levels of education and few soybean farmers were adopted non-institutional education. Length of experience in crop farming is also an important factor that influences farmers' level of adoption for new technologies. The average length of experience of soybean farmers was 5.08 years. On an average, $42.50 \%$ of the soybean farmers received training on improved technique of soybean production from the Department of Agricultural Extension (DAE) and Bangladesh Agricultural Research Institute (BARI). In the study areas, average farm size per household was estimated at 1.30 ha. However, the average yearly household net income was Tk. 1,66,679 of which $13.81 \%$ received from soybean production in all areas (Tk 23025). 
Table 1. Socio-economic profile of soybean producers in the study areas

\begin{tabular}{lc}
\hline Items & Responded sample farmer \\
\hline i. Farmer's age (year) & 47.18 \\
ii. Level of education (\%) & 15.00 \\
$\quad$ Illiterate & 49.66 \\
$\quad$ Primary & 11.81 \\
Secondary & 1.05 \\
$\quad$ Higher Secondary & 22.50 \\
$\quad$ Non institutional education & 24.77 \\
iii. Total Farming experience (year) & 5.08 \\
iv. Total soybean Farming experience (year) & 42.50 \\
v. Training received (\%) & 1.30 \\
vi. Farm size (ha) & 166679 \\
vii. Household income (Tk/yr) & 23025 \\
viii. Income from Soybean (Tk/yr/ha) & \\
\hline
\end{tabular}

Source: Field survey, 2013

\section{Management practice of soybean cultivation}

Appropriate input use and time of operation are essential for achieving higher yield and economic benefit. Therefore, it is important to know the existing level of technology in terms of agronomic practices, time of operation are presented in the Table 2. The table indicates that the maximum soybean farmers in the study areas followed recommendation of Bangladesh Agricultural Research Institute (BARI) for ploughing, leddering, sowing time, sowing technique, pest control and weeding. This may be due to more communication with scientist and agricultural extension officer about soybean production technology. This table also reveals that most of the farmers did not irrigate their soybean farm due to lack of irrigation water because they are dependent on rainfall to soybean production.

Table 2. Management practices used in soybean production

\begin{tabular}{|c|c|c|}
\hline Technology & $\%$ of farmers responded & Recommendation as BARI \\
\hline \multicolumn{3}{|l|}{ Plowing } \\
\hline 2-3 Nos. & $26.74^{-}$ & \\
\hline 4-5 Nos. & 73.27 & 4-5 Nos \\
\hline \multicolumn{3}{|l|}{ Laddering } \\
\hline 2-3 Nos. & 41.04 & \\
\hline 4-5 Nos. & 58.96 & 4-5 Nos \\
\hline \multicolumn{3}{|l|}{ Sowing time } \\
\hline Mid Dec.- Last Dec. & 7.36 & \\
\hline $1^{\text {st }}$ Jan.- Mid Jan. & 88.33 & Mid Dec. to Mid Jan. \\
\hline Mid Jan.-Last Jan. & 4.31 & \\
\hline \multicolumn{3}{|l|}{ Sowing technique } \\
\hline Broadcast & $42.71^{\circ}$ & \\
\hline Line sowing & 57.30 & Line sowing \\
\hline \multicolumn{3}{|l|}{ Irrigation provided } \\
\hline Not provided & 89.45 & \\
\hline 1 No.-2 Nos. & 10.56 & 2 Nos. \\
\hline \multicolumn{3}{|l|}{ Weeding } \\
\hline Not weeded & 2.15 & \\
\hline One time & 51.88 & 1-2 times \\
\hline Two times & 30.97 & \\
\hline Three times & 15.00 & \\
\hline \multicolumn{3}{|l|}{ Pest control } \\
\hline $1-2$ time use & 85.00 & Two times \\
\hline 3 - 4 time use & 15.00 & \\
\hline
\end{tabular}

Source: Field survey, 2013 


\section{Input use pattern of soybean and its competitive crops cultivation}

Human labour was mainly employed in land preparation, seed sowing, fertilizing, insecticiding, weeding, crop harvesting and threshing. It is revealed from the Table 3 that the groundnut farmer used higher amount of human labour compared to soybean, grasspea and cowpea production. In case of land preparation, cost was more or less same for soybean, groundnut and cowpea production but lower in grasspea production due to lower number of tillage needed for grasspea production. In the study area, per hectare use of chemical fertilizer was higher for soybean production compared to other competitive crops cultivation. Caterpillar is one of the most harmful insects for soybean. Hundred percent of total soybean farmers used pesticides to control insects like caterpillar and the use of pesticide was higher for soybean compared to other competitive crops cultivation to protect their crops.

Table 3. Input use pattern of soybean and competitive crops cultivation (per hectare)

\begin{tabular}{|c|c|c|c|c|}
\hline Items & Soybean & Groundnut & Cowpea & Grasspea \\
\hline \multicolumn{5}{|l|}{ Human labour (man-day) } \\
\hline Own & 48.40 & 55.64 & 32.89 & 21.63 \\
\hline Hired & 57.58 & 71.26 & 44.60 & 31.19 \\
\hline Total & 105.98 & 126.90 & 77.49 & 52.82 \\
\hline Land preparation cost (Tk.) & 5011.22 & 4924.5 & 5113.6 & 2120.1 \\
\hline Seed (Kg.) & 68.94 & 110.00 & 48.29 & 55.09 \\
\hline Manure (Kg.) & 508.17 & 110.06 & 9.56 & -- \\
\hline Urea (Kg.) & 45.94 & 33.38 & 28.10 & 27.40 \\
\hline TSP (Kg.) & 76.59 & 58.44 & 39.51 & 24.30 \\
\hline MP (Kg.) & 43.85 & 40.41 & 22.43 & 9.46 \\
\hline Gypsum (Kg.) & 20.07 & 1896 & 32.89 & 1692.4 \\
\hline Pesticide (Tk) & 2032.42 & 55.64 & 32.89 & 21.63 \\
\hline
\end{tabular}

Source: Field survey, 2013

\section{Cost of soybean and its competitive crops cultivation}

Total cost consists of variable cost and fixed cost that covered by $65.4 \%$ and $34.6 \%$ of the total cost for soybean production, $67.2 \%$ and $32.8 \%$ of total cost for groundnut production, $64.9 \%$ and $35.1 \%$ for cowpea production and $62.1 \%$ and $37.9 \%$ for grasspea production, respectively. Beside this, interest on operating capital was also considered as one of the component of the cost of production. It is found from the Table 4 that human labour cost is the major cost item in all crops cultivation which is $54.5 \%, 56.0 \%$, $53.9 \%$ and $49.9 \%$ for soybean, groundnut, cowpea and grasspea, respectively. Cost of seed is higher for groundnut cultivation compared to other competitive crops cultivation because the large amount of seed is required for groundnut cultivation. In the study areas, there is no farmer except soybean farmer who use gypsum for their selective crop cultivation. The cost of production was higher in groundnut cultivation compared to its competitive crops production due to higher labour and seed cost.

Table 4. Cost of soybean and competitive crops cultivation (Tk./ha)

\begin{tabular}{lcccc}
\hline Cost items & Soybean & Groundnut & Cowpea & Grasspea \\
\hline Land preparation & $5011.2(9.4)$ & $4924.3(7.8)$ & $5113.6(11.9)$ & $2120.1(7.1)$ \\
Hired labour & $15860.7(29.7)$ & $19838.3(31.5)$ & $13258.9(31.0)$ & $8837.9(29.5)$ \\
Seed & $6649.3(12.5)$ & $11358.2(18.0)$ & $4923.4(11.5)$ & $4038(13.5)$ \\
Manure & $451.7(0.8)$ & $165.1(0.3)$ & $11.5(0.03)$ & - \\
Urea & $925.1(1.7)$ & $667.5(1.1)$ & $561.9(1.3)$ & $548(1.8)$ \\
TSP & $1691.5(3.2)$ & $1285.6(2.0)$ & $602.8(1.4)$ & $534.5(1.8)$ \\
MP & $657.7(1.2)$ & $613.6(1.0)$ & $336.4(0.8)$ & $141.8(0.5)$ \\
Gypsum & $231.4(0.4)$ & -- & -- & -- \\
Pesticide & $2032.4(3.8)$ & $1896.0(3.0)$ & $1918.6(4.5)$ & $1692.3(5.6)$ \\
Interest on operating capital & $1340.5(2.5)$ & $1629.9(2.6)$ & $1069.1(2.5)$ & $716.5(2.4)$ \\
Total variable cost & $34851.5(65.4)$ & $42378.5(67.2)$ & $27796.2(64.9)$ & $18629.1(62.1)$ \\
Family labour & $13235.8(24.8)$ & $15442.3(24.5)$ & $9788.6(22.9)$ & $6127.5(20.4)$ \\
Rental value of land (for 4 month) & $5243.1(9.8)$ & $5243.1(8.3)$ & $5243.1(12.2)$ & $5243.1(17.5)$ \\
\hline Total fixed cost & $18478.9(34.6)$ & $20685.4(32.8)$ & $15031.7(35.1)$ & $11370.6(37.9)$ \\
Total cost & $53330.4(100.0)$ & $63063.9(100.0)$ & $42827.9(100.0)$ & $29999.7(100.0)$ \\
\hline
\end{tabular}

Source: Field survey, 2013

Note: Figures in the parentheses indicate percentage 


\section{Profitability and competitive advantage of soybean cultivation}

Table 5 represents that the average yield of soybean, groundnut, cowpea and grasspea was $1813 \mathrm{~kg} / \mathrm{ha}$, $1473 \mathrm{~kg} / \mathrm{ha}, 958 \mathrm{~kg} / \mathrm{ha}$ and $1076 \mathrm{~kg} / \mathrm{ha}$, respectively. Net return received by the farmers was higher for soybean production compared to its competitive crops production which was $27.73 \%$ higher to groundnut, $92.95 \%$ higher to cowpea and $158.11 \%$ higher to grasspea production, respectively. The benefit cost ratio (BCR) from soybean production were 1.43 and 2.18 over full cost and variable cost implying that Taka one investment in soybean production would generate Tk.1.43 and Tk 2.18, respectively which indicate the soybean cultivation at farm level is profitable. On the other hand, the benefits cost ratio (BCR) from groundnut were 1.26 on total cost basis and 1.88 on variable cost basis; from cowpea it was 1.28 on total cost basis; and 1.97 on variable cost basis; from grasspea production were 1.29 and 2.08 over full cost and variable cost basis respectively. Therefore, the farm level cultivation of these four crops is remunerative to the farmers as the BCR of all crops are higher than one. Even though, the cost of cultivation of soybean was higher than that of cowpea and grasspea except groundnut, its gross returns as well as net returns were also correspondingly higher than cowpea and grasspea. Similarly, benefit cost ratio was higher in case of soybean than that of groundnut, cowpea and grasspea. Therefore, the cultivation of soybean was more profitable crop than that of other competitive crops.

Table 5. Profitability and competitive advantage of soybean cultivation

\begin{tabular}{lcccc}
\hline Cost and return & Soybean & Groundnut & Cowpea & Grasspea \\
\hline A. Total cost & 53330.38 & 63063.7 & 42827.82 & 29999.6 \\
Variable cost (VC) & 34851.52 & 42378.32 & 27796.15 & 18629.1 \\
Fixed cost (FC) & 18478.87 & 20685.24 & 15031.67 & 11370.6 \\
Yield (kg/ha) & 1812.86 & 1472.85 & 871.225 & 1075.90 \\
B. Total return & 76107.30 & 79524.48 & 54632.63 & 38824.2 \\
C. Gross margin (B-VC) & 41255.78 & 37146.2 & 26836.5 & 20195.1 \\
D. Net return (B-A) & 22776.92 & 16460.8 & 11804.8 & 8824.6 \\
E. Rate of return (BCR) & & & & 1.28 \\
BCR on full cost & 1.43 & 1.26 & 1.97 & 1.29 \\
BCR on variable cost & 2.18 & 1.88 & 2.08 \\
\hline
\end{tabular}

Source: Author's calculation, 2013

\section{Input output relationship of soybean cultivation}

The coefficient of multiple determinations $\left(R^{2}\right)$ was 0.59 for soybean cultivation implying that the explanatory variables included in the model explained $59 \%$ of the total variation in yield for soybean production. The F-value of the equations is significant at $1 \%$ level implying that the variation in yield from soybean production depends mainly upon the explanatory variables included in the model. Estimated values of coefficient and related statistics of Cobb-Douglas production function of soybean is presented in Table 6. The coefficient of MP $\left(X_{5}\right)$ and gypsum $\left(X_{6}\right)$ was found to be positive and significant at $1 \%$ level which indicates that $1 \%$ increase in MP and gypsum keeping other factors remaining constant, would increase the yield by 0.147 and 0.126 percent for soybean production; and the coefficient of TSP $\left(\mathrm{X}_{4}\right)$ and pesticide $\left(X_{7}\right)$ were positive and significant at $5 \%$ level. On the other hand, the coefficient of seed $\left(X_{2}\right)$ was negative and significant at $1 \%$ implies that $1 \%$ increase in seed, keeping other factor constant, would decrease the yield of soybean by $0.243 \%$.

\section{Comparative advantage of soybean production}

Domestic resources, non-traded inputs and traded inputs which are used in producing soybean are important consideration for working out domestic resource cost (DRC). Domestic resources and nontraded inputs included human labour, power tiller, seed, manure, pesticides, land rent, interest on operating capital, etc. while traded inputs were urea, TSP, MP and gypsum. DRC indicates whether the domestic economy has a comparative advantage in soybean production relative to other countries. Value of tradable soybean is calculated the summation of FOB price of soybean, ship freight charge, import handling cost, transport cost and domestic trading cost. The finding of the study revealed that the DRC value for soybean production was 0.55 . It clearly indicates that the production of soybean in Bangladesh has comparative advantage rather than import (Table 7). 
Table 6. Estimated values of coefficients and related statistics of Cobb-Douglas Production model for soybean cultivation

\begin{tabular}{lcc}
\hline Explanatory variables & Coefficients & t-value \\
\hline Intercept & $13.188(1.353)$ & 9.749 \\
Human labour $\left(X_{1}\right)$ & $-0.022(0.071)$ & -0.308 \\
Seed $\left(X_{2}\right)$ & $-0.243^{\star \star \star}(0.090)$ & -2.695 \\
Urea $\left(X_{3}\right)$ & $-0.063(0.053)$ & 1.187 \\
TSP $\left(X_{4}\right)$ & $0.023^{\star \star}(0.094)$ & 2.099 \\
MP $\left(X_{5}\right)$ & $0.147^{\star \star \star}(0.057)$ & 2.593 \\
Gypsum $\left(X_{6}\right)$ & $0.126^{\star \star *}(0.031)$ & 4.036 \\
Pesticide $\left(X_{7}\right)$ & $0.048^{\star \star}(0.022)$ & 2.192 \\
$R^{2}$ & 0.59 & \\
F & $5.803^{\star \star *}$ & \\
\hline
\end{tabular}

Source: Field survey, 2013

${ }^{\star * \star}$ Significant at $1 \%$ level, ${ }^{*}$ Significant at $5 \%$ level, *Significant at $10 \%$ level and parenthesis indicate the standard error value.

Table 7. Comparative advantage of soybean production in Bangladesh

\begin{tabular}{lc}
\hline Items & (Tk./Metric tones) \\
\hline A. Traded input costs & 4347.82 \\
B. Non-traded input costs & 27484.06 \\
Land preparation cost & 2764.26 \\
Labour cost & 16050.06 \\
Seed cost & 3667.87 \\
Manure cost & 249.18 \\
Pesticide cost & 1121.11 \\
Rental value of land & 2892.16 \\
Interest on operating capital & 739.41 \\
C. Value of tradable soybean & 54676.43 \\
Domestic Resource Cost (DRC) & 0.55 \\
\hline
\end{tabular}

Source: Authors' calculation, 2013

\section{Farmers' attitudes toward soybean cultivation}

The soybean cultivating farmers were asked to mention the possibility of expanding their cultivated area for soybean production. Most of the farmers indicated that they would increase soybean area in the next year due to various advantages such as advance loan facility from private feed company, marketing facility, higher profit, short duration crop, less production cost and produce higher yield, etc. A good number of soybean farmers also wanted to increase area for the year due to meet up their household demand and for its multi-purpose uses. Some soybean farmers also mentioned various reasons for not expanding their soybean areas for the next year. The important reasons were lack of enough land, as they need to grow other crops and lack of HYV seed.

\section{Farm level constraints to soybean cultivation}

The sample farmers in the study areas mentioned numerous issues regarding the problems of soybean production. Major part of soybean growers mentioned the scarcity of fertilizers and its price hike as crucial problems followed by lack of capital. Some farmers mentioned non-availability of improve variety seed, infestation of soybean by hairy caterpillar. The lack of adequate technical know-how about soybean production also constrained some farmers to its higher production. Farmers also opined that they could not attain expected yield due to these constraints. 


\section{Conclusion}

This study assesses the competitive and comparative advantage of soybean cultivation at farm level. The study concludes that the agronomic practice is very encouraging because most of the farmers followed agronomic practices more or less to the recommendation except irrigation. Although some feed company gave advance cash to cultivate soybean but they did not utilize their cash properly. Soybean cultivation at farm level is found to be profitable since the average benefit cost ratio (BCR) on investment is 1.43 on full cost basis for soybean which indicates at farm level soybean production is more profitable. The farm level cultivation of soybean and its competing crops is remunerative to the farmers as the BCR of all crops are higher than one. Even though the cost of cultivation of soybean was higher than that of cowpea and grasspea except groundnut, its gross returns as well as net returns were also correspondingly higher than cowpea and grasspea. Soybean crop is gaining popularity in the country very quickly due to its high yield potential. A good opinion came out from the sample farmers that higher yield and income encourage them for continuing soybean cultivation, although many farmers have showed negative attitude toward its production because of various setbacks. They have experienced different socio-economic constraints to soybean production such as scarcity of fertilizers with its peak price, infestation of insects, and natural calamities. Lack of HYV seed availability is also found to be a barrier to the adoption of soybean. Information like proper sowing time, seed rate, fertilizer dose need to be provided to the farmers in order to increase the production. The government should encourage private seed companies to come forward for producing HYV seed production; strong extension programme and proper monitoring by the field staff need to ensure to increase area under soybean production as soybean is more profitable compared to its competing crops; credit should be supplied to the poor farmers with cover interest and easier terms; finally, attempts will also be made to introduce modern variety replacing the low yielding local varieties by motivating farmers through training, demonstration trials and motivation.

\section{Acknowledgments}

The study was financially supported by Research Management Committee (RMC) in 2013 at Bangabandhu Sheikh Mujibur Rahman Agricultural University (BSMRAU), Bangladesh.

\section{References}

Ashaye, O.A., Adegbulugbe, T.A. and Sanni, S. 2005. Assessment of soybean processing technologies in llorin East and West Local Government Area of Kwara State. World J. Agril. Sci., 1(1): 59-61.

BARI, 2009. Booklet on Bangladesh Agricultural Research Institute Soybean 5, Oilseed Research Centre, BARI, Gazipur.

BBS, 2013. Statistical Yearbook of Bangladesh, Bangladesh Bureau of Statistics, Statistics Division, Ministry of Planning, Government of People's Republic of Bangladesh, Dhaka.

Olorunsanya, E.O., Babatunde, R.O., Orebiyi, J.S. and Omotosho, J.O. 2009. Economic analysis of soybean production in kwara state, North central Nigeria, Global Approaches to Extension Practice (GAEP), 5(2): 45-53.

Hossain, M.I, Matin, M.A., Alam, M.S. and Ahmed M. 1992. Socio-Economic Study of Soybean in Some Selected Areas of Bangladesh, Bangladesh J. Argi. Res. 17(1): 7-12.

Mayta, J.P., Chen, Popp, M.P., Dong, D., Wu, C.J., Zhang, B., Smith, S.F. and Scaboo, A.M. 2014. Break-Even Profitability for Food-Grade Specialty Soybeans Agricultural Science, Published by Science and Education Centre of North America, 2(2): 01-11.

Jaiswal, A and Hugar L.B. 2011. An economic analysis of soybean cultivation vis-à-vis its competing crops in Madhya Pradesh, Karnataka J. Agric. Sci., 24(4): 591-592.

Punit, K.A. and Singh O.P. 2013. An Economic Analysis of Soybean Cultivation in Narsinghpur District of Madhya Pradesh, India, Indian J. Agri. Res., 48(3): 185-191.

Ogunsumi, L.O., Adegbite, A.A. and Oyekan, P.O. 2007. Economic Impact Assessment for Technology: The Case of Improved Soybean Varieties in Southwest Nigeria, J. Agri. and Rural Dev. in the Tropics and Subtropics, 108(1):79-86.

Salam, M.A. and Miah, M.A.M. 2013. Socio-Economic Assessment of Oilseed Crops Production in Bangladesh. Ann. Bangladesh Agric. 17(1\&2): 241-262.

Rashid, M.A. 2009. Trade Policies and Comparative Advantage in Bangladesh Agriculture, Ph.D Thesis, Department of Agricultural Economics, Bangladesh Agricultural University, Mymensingh, p. 34. 